Indonesian Journal of Nutrition and Dietetics Vol. 5, Issue 2, 2017: 51-59
Available online at: http://ejournal.almaata.ac.id/index.php/IJND DOI : http://dx.doi.org/10.21927/ijnd.2017.5(2).51-59

\title{
Development of low sodium salted eggs and its antioxidant potential
}

\author{
Setyaningrum Ariviani, Nur Hikmah Fitriasih, Dwi Ishartani
}

Department of Food Science and Technology, Faculty of Agriculture, Universitas Sebelas Maret, Jalan Ir. Sutami No 36A Kentingan, Surakarta, Indonesia

*Corresponding author: setya_ariviani@yahoo.com

\begin{abstract}
Background: Salted egg is one of processed egg products which has a nutrient content that is comparable to the fresh egg, has a longer shelf life and can be consumed by all ages. The main process in the salted egg production is salting $(\mathrm{NaCl})$ treatment that will give salty taste and acts as a preservative. Objectives: This study aimed to develop low-sodium salted eggs with an antioxidant potential through the innovations in the salting process.

Methods: This was an experimental research. Salted eggs were produced with innovations in salting process using various concentration of teak leave extract and potassium chloride (KCl) substitution. The sensory qualities of the salted eggs were determined using differential tests. Salted eggs with the best sensory quality were determined their nutritional quality with proximate measurements and their antioxidative potency by measuring total phenolic content and antioxidant activity.

Results: The research result showed that the $\mathrm{KCl}$ substitution did not affect the total phenolic content (TPC) of salted eggs, but it reduced the sensory qualities which include the quality of taste, color, flavor and overall. The addition of teak leave extracts improved both the sensory quality and TPC of salted eggs produced with $\mathrm{KCl}$ substitutions. TPC increased along with increased of teak leave extract concentrations. $\mathrm{KCl}$ substitution or addition of teak leaves extract proved to increase the radical scavenging activity of salted eggs. The low-sodium salted egg with an antioxidant potential which was made using selected salting formulation had nutritional and sensory qualities which comparable to the salted eggs produced using sodium chloride ( $\mathrm{NaCl}$ ).

Conclusion:The low-sodium salted eggs have antioxidant potential that can be produced by salting process innovation using teak leave extract and $\mathrm{KCl}$ substitution.
\end{abstract}

KEYWORDS: salted egg, $\mathrm{KCl}$, teak leave extracts, antioxidants, sensory

\section{INTRODUCTION}

Eggs are foods with good nutritional density, sources of protein, vitamin $A$, folate, selenium, choline, phosphorus, and rich in vitamin D, B12, riboflavin, biotin, and iodine. Compared to other animal protein sources, eggs provide lower calories and the richest mix of essential amino acids as well as having the best protein quality with NPU (net protein utilization) value reaching 96.5 - $97.5(1,2,3)$. On the other hand, eggs are susceptible to damage, either natural damage, chemical damage or microbiological damage caused by microorganisms attack through the pores of the egg. One common egg preservation technique that easy, cheap, simple and able to maintain the nutritional value of eggs is by processing into salted egg products.
The quality of salted eggs other than affected by shelf life is also influenced by the sensory quality which includes taste, aroma, and the egg yolk color and texture. The characteristics of a high quality salted egg are had enough salty taste, the egg yolks have orange to reddish color and sandiness texture, dry (not juicy), no fishy odor, and oily on the edge of egg yolks. Characteristics of egg yolk is a major factor determining consumer acceptance and market demand $(4,5,6)$.

Based on the processing methods, salted egg can be made by immersing eggs in saturated saline or by coating the egg with the salt paste containing salt, ash, and brick powder. Higher hardness and adhesiveness were found in yolk with the paste coating method, whereas greater fracturability, gumminess, and chewiness were observed with the 
immersing method (6). The main process of making salted eggs is salting (using $\mathrm{NaCl}$ ) which will provide salty taste and also serves as a preservative.

Increased of sodium $(\mathrm{NaCl})$ intake and the deficiency of potassium is a pathophysiology of hypertension. The prevalence of hypertension and stroke risk were positively correlated with sodium intake and negatively correlated with potassium intake. The modified diet with the potassium : sodium ratio of 2 is a very important strategy for the prevention and treatment of hypertension (7). The results of research conducted by Anggara and Prayitno (8) showed that the incidence of hypertension was more common among respondents whose sodium intake was frequent $(61.3 \%)$ than respondents whose sodium intake was not frequent $(9.1 \%)$. There was a significant correlation between potassium intake with blood pressure $(p=0.04)$, the incidence of hypertension was more common among respondents whose intake of potassium was not frequent $(51.7 \%)$ than respondents who had frequent potassium intake $(17.4 \%)$. The sodium-potassium ratio is a major factor affecting blood pressure and the incidence of hypertension (9). $\mathrm{KCl}$ intakes have been shown to decrease cytosolic blood pressure in hypertensive rats (10). When potassium intake is increased, high intake of sodium is not associated with higher blood pressure (11).

This study aimed to examine the use of $\mathrm{KCl}$ and teak leave extract in various proportions for the production of low-sodium salted eggs having antioxidant potential, in terms of sensory quality (color, taste, aroma, texture, and overalls), antioxidant capacity (total phenolic content and free radical scavenging activity), and nutritional values (protein, fat, total mineral, water, and carbohydrate levels). $\mathrm{KCl}$ was used for $\mathrm{NaCl}$ substitution in salting process. The use of teak leaves is intended to improve the color quality as well as enriching antioxidants of salted eggs. Teak leaves buds are culturally used as a natural food coloring. Research of Hartati et al. (12) showed that teak leave ethanol extract containing flavonoids and phenolic compounds. Both of these compounds have been reported to have capacity as antioxidants $(13,14)$.

\section{MATERIALS AND METHODS}

The materials used in this study include: Duck eggs, sodium salt $(\mathrm{NaCl})$, and ash from the local market, potassium salt $(\mathrm{KCl})$ "food grade" obtained from Bratachem Surakarta, teak leave buds (light green colour, soft texture) and bricks powder were obtained from Palur (Surakarta, Indonesia) region, chemical reagents: DPPH (2,2-diphenyl-1picrylhydrazyl) and $\mathrm{BHT}$ (butylated hydroxytoluene) were obtained from Sigma-Aldrich Co. (S. Louis, $\mathrm{MO}, \mathrm{USA}$ ), Na2CO3, folin-ciocalteau reagents, phenol, and methanol from Merck Millipore Co. (Darmstadt, Germany), aquadest and reagents of proximate analysis were obtained from the Food and Nutrition Laboratory, Faculty of Agriculture Universitas Sebelas Maret. The research equipment used was equipment for salted egg production, glassware, magnetic stirrer (Thermo Fisher Scientific Inc., USA), a set of sensory analysis tools, Uv-vis spectrophotometers (Genesys 10S, Thermo Fisher scientific Inc., USA), Oven (Memmert, Germany), Muffle furnaces, a set of Kjeldahl tools, a set of soxhlet extraction tools, mortar, vortex.

\section{Preparation of salted eggs}

Salted eggs prepared using salt paste which was a brick-ash-salt mixture (2:1:1) with and without $\mathrm{KCl}$ substitution or teak leave extract addition. The proportion of $\mathrm{KCl}$ used was $(3: 2)$ or $(2: 1)(\mathrm{w} / \mathrm{w})$ of $\mathrm{NaCl}$. Teak leave extract obtained from extraction of teak leave buds using distilled water (1:1) which stirred using magnetic stirrer (2500 rpm, 15 minutes). Salted eggs preparation was conducted by coating duck eggs using salt paste, followed by incubation for 14 days. After incubation, the salt paste coating was removed, then the eggs were boiled

\section{Sensory analysis using difference test with multiple comparison test method (15)}

Sensory analysis carried out in this study comprised a sensory analysis for the selection of salt paste formulas and sensory analysis for the determination of the sensory quality of the salted eggs prepared using selected salt paste formula. The selection of salt paste formula was carried 
out by comparing the color, taste, texture, and overall qualities of the salted egg samples with a reference sample $(R$, control salted egg: without $\mathrm{KCl}$ substitution or teak leave extract addition) using 30 semi-trained panelists. Panelists were asked to show the difference between the sample and the reference $(R)$, whether better, equal or worse and determine the difference intensity. Score 1: very much better than $R, 3$ : better than $R$, 5 : equal to $R, 7$ : worse than $R$ and 9: very worse than $R$. The salt paste formula that produces salted eggs with comparable sensory qualities with the reference sample (R) was selected for further investigation.

Sensory analysis for the sensory quality determination of salted eggs produced using selected salt paste formulas was conducted in the same manner as the sensory analysis for salt paste formula selection, but the parameters tested were slightly different, i.e. egg white color, egg yolk color, taste, flavor, texture, and overall qualities.

\section{Analysis of antioxidant potential of salted eggs}

The antioxidant potential analysis of salted eggs was carried out by measuring the total phenolic content and antioxidant activity. The total phenolic content was analyzed by the Folin-Ciocalteu method (Singleton and Rossi, 1965 in Yan et al (16). Antioxidant activity was evaluated by radical scavenging activity (RSA) measurement using DPPH method (17) and expressed as (\%) RSA per $100 \mathrm{~g}$ (dry weight).

RSA $(\%)=\left(1-\frac{\text { absorbance of sample }}{\text { absorbance of control }}\right) \times 100 \%$

\section{Antioxidant activity $=(\% R S A / 100 g$ dry weight $)$}

\section{Nutritional analysis of salted eggs by proximate measurement (AOAC, 1990) (18)}

Nutritional analysis of salted eggs were conducted by measuring protein, fat, total minerals and carbohydrates content. Total protein content was determined by the Kjeldahl method, fat content by soxhlet extraction method, total mineral and moisture content by gravimetric, and carbohydrate content (by different).

\section{Data analysis}

The data were analyzed using SPSS Statistics 17.0 program with Analysis of variance (ANOVA) test at significance level of $5 \%(p<0.05)$ to determine the effect of treatment. Duncan's Multiple Range

Table 1. Sensory qualities of salted eggs prepared using various salt paste formulation

\begin{tabular}{|c|c|c|c|c|}
\hline \multirow{2}{*}{ Salted eggs with various salt paste formulation } & \multicolumn{4}{|c|}{ Score of sensory quality $\left({ }^{*}\right)$} \\
\hline & Color & Taste & Texture & Overall \\
\hline Control ( $\mathrm{NaCl}+$ brick-ash mixture $)$ & $5.01 \pm 0.61^{\mathrm{bc}}$ & $5.63 \pm 0.64^{\text {cd }}$ & $5.0 \pm 0.43^{\mathrm{cd}}$ & $4.64 \pm 0.46^{c}$ \\
\hline $\mathrm{P} 1$ (KCl: $\mathrm{NaCl}(3: 2)+$ brick-ash mixture) & $6.30 \pm 1.98^{d}$ & $5.88 \pm 1.9^{d}$ & $5.70 \pm 1.74^{\mathrm{cd}}$ & $6.15 \pm 1.54^{\mathrm{d}}$ \\
\hline $\mathrm{P} 2$ (KCl: $\mathrm{NaCl}(2: 1)+$ brick-ash mixture) & $5.58 \pm 1.73^{\mathrm{cd}}$ & $7.03 \pm 1.55^{\mathrm{e}}$ & $4.76 \pm 1.63^{\mathrm{bc}}$ & $5.82 \pm 1.67^{\mathrm{cd}}$ \\
\hline $\begin{array}{l}\text { P1E1 ( } \mathrm{KCl}: \mathrm{NaCl}(3: 2)+\text { brick-ash mixture + teak leave } \\
\text { extract } 50 \%)\end{array}$ & $4.85 \pm 1.73^{\mathrm{bc}}$ & $5.73 \pm 2.34^{d}$ & $4.76 \pm 1.64^{\mathrm{bc}}$ & $5.77 \pm 2.05^{\mathrm{bc}}$ \\
\hline $\begin{array}{l}\text { P2E1 ( } \mathrm{KCl}: \mathrm{NaCl}(2: 1)+\text { brick-ash mixture + teak leave } \\
\text { extract } 50 \%)\end{array}$ & $4.61 \pm 1.87^{b}$ & $5.42 \pm 1.48^{\mathrm{cd}}$ & $5.06 \pm 1.12^{\mathrm{cd}}$ & $5.15 \pm 1.60^{\mathrm{bc}}$ \\
\hline $\begin{array}{l}\text { P1E2 (KCl: } \mathrm{NaCl}(3: 2)+\text { brick-ash mixture + teak leave } \\
\text { extract } 75 \%)\end{array}$ & $4.21 \pm 2.07^{\mathrm{b}}$ & $4.82 \pm 2.01^{c}$ & $4.55 \pm 1.66^{\mathrm{bc}}$ & $4.64 \pm 1.65^{c}$ \\
\hline $\begin{array}{l}\text { P2E2 (KCl: } \mathrm{NaCl}(2: 1)+\text { brick-ash mixture + teak leave } \\
\text { extract } 75 \%)\end{array}$ & $3.21 \pm 1.24^{\mathrm{a}}$ & $3.85 \pm 2.03^{b}$ & $5.0 \pm 1.90^{\mathrm{cd}}$ & $3.79 \pm 1.62^{a}$ \\
\hline $\begin{array}{l}\text { P1E3 (KCl: } \mathrm{NaCl}(3: 2)+\text { brick-ash mixture + teak leave } \\
\text { extract } 100 \%)\end{array}$ & $2.97 \pm 1.43^{a}$ & $2.94 \pm 1.37^{a}$ & $4.12 \pm 2.12^{\mathrm{ab}}$ & $3.67 \pm 1.57^{\mathrm{a}}$ \\
\hline $\begin{array}{l}\text { P2E3 (KCl: } \mathrm{NaCl}(2: 1) \text { +brick-ash mixture + teak leave extract } \\
100 \%)\end{array}$ & $3.21 \pm 1.24^{a}$ & $3.00 \pm 1.37^{a}$ & $3.61 \pm 1.64^{a}$ & $3.79 \pm 1.62^{a}$ \\
\hline
\end{tabular}

The number followed by the same letter in the same column shows no significant difference $(p>0.05) .\left(^{*}\right)$ : Score 1 = very much better than $\mathrm{R}, 3=$ better than $\mathrm{R}, 5=$ equal to $\mathrm{R}, 7=$ worse than $\mathrm{R}, 9=$ very much worse than R. R: salted egg with salt paste control ( $\mathrm{NaCl}+$ brick-ash mixture) 
Test (DMRT) at the same level of significance was conducted to determine the difference between treatments. Data were presented in the average of three replications and its standard deviation.

\section{RESULTS}

\section{The salt paste formulation}

The formulation of salt paste carried out in this study consisted of 9 formulas, i.e: control (without KCL substitution, without teak leave extract), $\mathrm{P} 1, \mathrm{P} 2$, P1E1, P1E2, P2E1, P2E2, P1E3, and P2E3. P1 and $P 2$ were the formulas with $\mathrm{KCl}$ substitution, without teak leave extract. The $\mathrm{KCl}: \mathrm{NaCl}$ ratio was (3:2 $\mathrm{w} / \mathrm{w})$ for $\mathrm{P} 1$ and $(2: 1 \mathrm{w} / \mathrm{w})$ for $\mathrm{P} 2$. P1E1 was $\mathrm{P} 1$ with adding $25 \%$ of teak leave extract $50 \%$, P1E2 was P1 with adding $25 \%$ of teak leave extract $75 \%$, P1E3 was P1 with adding $25 \%$ of teak leave extract $100 \%$, P2E1 was P2 with adding $25 \%$ of teak leave extract $50 \%$, P2E2 was P2 with adding $25 \%$ of teak leave extract $75 \%$ and P2E3 was P2 with adding $25 \%$ of teak leave extract $100 \%$. The salt paste formula was selected based on the sensory analysis result which consists of color, taste, texture, and overall qualities conducted with multiple comparison tests using 30 semi-trained panelists. The salted egg produced with control formula was used as a comparison. The sensory qualities data of salted eggs with various salt paste formulas are presented in Table 1.

The addition of teak leaves extract $50 \%$ could improve the color quality, but has not been able to improve the taste quality of salted eggs that decreased due to $\mathrm{KCl}$ substitution. Salted eggs prepared with this formula show a slightly worse taste quality than those of control formula (without $\mathrm{KCl}$ substitution). Addition of teak leave extract $75 \%$ with the $\mathrm{KCl}: \mathrm{NaCl}$ ratio of (3: $2 \mathrm{w} / \mathrm{w}$ ) (P1E2) showed the same color, taste, texture and overall quality as salted eggs prepared without $\mathrm{KCl}$ substitution (control formula). The salt paste formulas that produce salted eggs which have the better sensory quality of color, taste, texture, and overalls rather than control formula were salt paste with the addition of teak leave extract 100\% (P1E3 and P2E3) and teak leave extract $75 \%(P 2 E 2)$. These three formulas were selected for further study. P1, P2, and control formulas were used as the comparison to determine the effect of $\mathrm{KCl}$ substitution, the effect of the addition of teak leave extract and the effect of their interaction.

\section{Antioxidant potency of salted eggs prepared with selected salt paste formulas}

The antioxidant potency of salted eggs prepared with selected salt paste formula, consisting of the total phenolic content and antioxidant activity was presented in Table 2.

Based on the data in Table 2, it is known that $\mathrm{KCl}$ substitution had no effect on total phenolic content but increased the free radical scavenging activity of salted eggs. The use of teak leave extract significantly increases the total phenolic content of salted eggs thus increasing its antioxidant activity.

\section{Nutritional quality of salted eggs prepared with selected salt paste formula}

The nutrient quality of salted eggs prepared using selected salt paste formulas and control

Table 2. Antioxidant potency of salted eggs prepared using various salt paste formulation

\begin{tabular}{lcc}
\hline \multicolumn{1}{c}{ Salted eggs with various salt paste formulation } & $\begin{array}{c}\text { Total phenolic content } \\
\text { (mg/100g dry weight) }\end{array}$ & $\begin{array}{c}\text { Antioxidant activity } \\
\text { ((\%) RSA/ 100g dry weight) }\end{array}$ \\
\hline Control $(\mathrm{NaCl}+$ brick-ash mixture) & $126.26 \pm 6.96^{\mathrm{a}}$ & $4.49 \pm 0.38^{\mathrm{a}}$ \\
P1 $(\mathrm{KCl}: \mathrm{NaCl}(3: 2)+$ brick-ash mixture) & $144.87 \pm 2.96^{\mathrm{a}}$ & $14.74 \pm 0.66^{\mathrm{b}}$ \\
P2 $(\mathrm{KCl}: \mathrm{NaCl}(2: 1)+$ brick-ash mixture) & $152.11 \pm 18.99^{\mathrm{ab}}$ & $21.25 \pm 0.73^{\mathrm{c}}$ \\
P2E2 $(\mathrm{KCl}: \mathrm{NaCl}(2: 1)+$ brick-ash mixture + teak leave & & \\
extract $75 \%)$ & $175.29 \pm 3.16^{\mathrm{b}}$ & $52.28 \pm 3.88^{\mathrm{d}}$ \\
P1E3 $(\mathrm{KCl}: \mathrm{NaCl}(3: 2)+$ brick-ash mixture + teak leave & & \\
extract $100 \%)$ & $211.03 \pm 13.12^{\mathrm{c}}$ & $59.70 \pm 2.80^{\mathrm{e}}$ \\
P2E3 $(\mathrm{KCl}: \mathrm{NaCl}(2: 1)+$ brick-ash mixture + teak leave & $229.65 \pm 26.65^{\mathrm{c}}$ & $72.47 \pm 1.90^{\mathrm{f}}$ \\
extract $100 \%)$ & & \\
\hline
\end{tabular}

The numbers followed by the same letter show no significant difference $(p>0.05)$ 
Table 3. Nutritional quality of salted eggs prepared with selected salt paste formula

\begin{tabular}{|c|c|c|c|c|c|}
\hline \multirow[b]{2}{*}{$\begin{array}{c}\text { Salted eggs with various salt paste } \\
\text { formulation }\end{array}$} & \multicolumn{5}{|c|}{ Nutrition composition (\% dry weight) } \\
\hline & Moisture & $\begin{array}{c}\text { Total } \\
\text { minerals }\end{array}$ & Protein & Fat & Carbohydrate \\
\hline Control ( $\mathrm{NaCl}+$ brick-ash mixture) & $67.46 \pm 1.04$ & $6.12 \pm 0.26$ & $29.08 \pm 1.30$ & $48.32 \pm 1.64$ & $20.48 \pm 3.06$ \\
\hline $\begin{array}{l}\text { P2E2 ( } \mathrm{KCl}: \mathrm{NaCl}(2: 1)+\text { brick-ash mixture + } \\
\text { teak leave extract } 75 \%)\end{array}$ & $67.18 \pm 1.18$ & $6.46 \pm 0.20$ & $26.98 \pm 1.08$ & $44.57 \pm 0.97$ & $22.00 \pm 0.16$ \\
\hline $\begin{array}{l}\text { P1E3 (KCl: } \mathrm{NaCl}(3: 2)+\text { brick-ash mixture + } \\
\text { teak leave extract } 100 \%)\end{array}$ & $66.43 \pm 1.20$ & $5.09 \pm 0.69$ & $35.33 \pm 0.77$ & $43.98 \pm 3.86$ & $16.68 \pm 2.65$ \\
\hline $\begin{array}{l}\text { P2E3 (KCl: } \mathrm{NaCl}(2: 1)+\text { brick-ash mixture + } \\
\text { teak leaveextract } 100 \%)\end{array}$ & $65.70 \pm 0.84$ & $5.01 \pm 1.17$ & $28.45 \pm 0.78$ & $43.37 \pm 1.28$ & $23.17 \pm 2.33$ \\
\hline
\end{tabular}

formula is presented in Table 3. The data in Table 3 indicated that the development of low-sodium salted eggs having antioxidant potential through innovation in salting process with $\mathrm{KCl}$ substitution and the addition of teak leave extract exhibits a comparable nutritional quality to the salted eggs which prepared with the control formula.

\section{Sensory quality of salted eggs prepared with selected salt paste formula}

Table 4 showed that salted eggs produced using $\mathrm{KCl}$ substitution and the addition of teak leave extract have comparable sensory quality with salted eggs produced using control formula. The sensory quality tested includes egg white and yolk colors, flavor, taste, and overall.

\section{DISCUSSION}

\section{The salt paste formulation}

Based on the sensory quality data in Table 1 , it can be seen that $\mathrm{KCl}$ substitution resulted in decreasing quality of color, flavor, and overall but have no effect on the texture (mouthfeel) quality. The addition of teak leave extract reduced the degradation of the sensory quality due to $\mathrm{KCl}$ substitution. The higher concentration of teak leave extract, not only reduced the quality decline, even it was able to improve the sensory qualities of salted eggs.

\section{Antioxidant potency of salted eggs prepared with selected salt paste formulas}

The antioxidant potential of salted eggs was determined by measuring the total phenolic content and also antioxidant activity especially free radical scavenging. This was based on Hartati research (12) which state that teak leave ethanol extract contains phenolic compounds. Phenolic compounds are known to act as antioxidants by scavenging free radicals through hydrogen donor mechanisms in ROS (reactive oxygen species) or RNS (reactive nitrogen species), so it inhibits the free radical chain reaction $(14,19)$.

Total phenolic content and antioxidant activity of salted eggs made by selected salt paste formula are presented in Table $\mathbf{2}$. Salted eggs made by the control formula (using $\mathrm{NaCl}$ only) showed free radical scavenging activity. This was related to the presence of carotenoid pigments present in egg yolks and their phenolic compounds. The yellow color intensity of the yolk was influenced by the carotenoid content of the feed.The higher carotenoid content in the feed, the duck egg yolk index increased (20). Saty et al. (21) showed that duck eggs have $\beta$-carotene levels in the range of $899-977 \mathrm{mg} / 100 \mathrm{~g}$. It was influenced by the location of the cultivation. Table 2 showed that salted eggs prepared with control formula have a total phenolic content of $126.26 \pm 6.96 \mathrm{mg} / 100 \mathrm{~g}$ dry weight. One of the mechanisms caused the phenolic compounds providing protective effects against some diseases was the ability of phenolic compounds in scavenging free radicals thus protect biomolecules such as lipids, proteins, and DNA from damages by oxidative stress (22).

The total phenolic content of salted eggs with $\mathrm{KCl}$ substitution was not significantly different from salted eggs without $\mathrm{KCl}$ substitution (using $\mathrm{NaCl}$ only) (Table 2). This indicated that $\mathrm{KCl}$ substitution did not affect the total phenolic content of salted 
Table 4. Sensory qualities of salted eggs prepared with selected salt paste formula

\begin{tabular}{|c|c|c|c|c|c|c|}
\hline \multirow{2}{*}{$\begin{array}{l}\text { Salted eggs with various salt } \\
\text { paste formulation }\end{array}$} & \multicolumn{6}{|c|}{ Score of sensory quality $\left({ }^{*}\right)$} \\
\hline & $\begin{array}{l}\text { Egg yolk } \\
\text { color }\end{array}$ & $\begin{array}{l}\text { Egg white } \\
\text { color }\end{array}$ & Flavour & Taste & Texsture & Overall \\
\hline $\begin{array}{l}\text { Control }(\mathrm{NaCl}+\text { brick-ash } \\
\text { mixture) }\end{array}$ & $4.9 \pm 0.24^{c}$ & $4.97 \pm 0.17^{\mathrm{b}}$ & $4.88 \pm 0.33^{c}$ & $4.91 \pm 0.46^{d}$ & $4.97 \pm 0.43^{b}$ & $4.85 \pm 0.36^{c}$ \\
\hline $\begin{array}{l}\mathrm{P} 2 \mathrm{E} 2(\mathrm{KCl}: \mathrm{NaCl}(2: 1)+\text { brick-ash } \\
\text { mixture + teak leave buds extract } \\
75 \%)\end{array}$ & $3.91 \pm 1.07^{\mathrm{b}}$ & $4.70 \pm 0.53^{a}$ & $4.12 \pm 0.70^{\mathrm{b}}$ & $4.30 \pm 1.38^{c}$ & $4.33 \pm 1.27^{a}$ & $4.03 \pm 0.85^{b}$ \\
\hline $\begin{array}{l}\mathrm{P} 1 \mathrm{E} 3(\mathrm{KCl}: \mathrm{NaCl}(3: 2)+\text { brick-ash } \\
\text { mixture + teak leave buds extract } \\
100 \%)\end{array}$ & $3.18 \pm 1.01^{\mathrm{a}}$ & $4.88 \pm 0.42^{\mathrm{ab}}$ & $3.33 \pm 0.78^{a}$ & $3.21 \pm 0.75^{b}$ & $4.55 \pm 1.32^{\mathrm{ab}}$ & $3.58 \pm 0.88^{a}$ \\
\hline $\begin{array}{l}\mathrm{P} 2 \mathrm{E} 3(\mathrm{KCl}: \mathrm{NaCl}(2: 1)+\text { brick-ash } \\
\text { mixture + teak leave buds extract } \\
100 \%)\end{array}$ & $3.61 \pm 1.23^{\mathrm{ab}}$ & $4.79 \pm 0.65^{\mathrm{ab}}$ & $3.21 \pm 0.89^{a}$ & $2.76 \pm 0.98^{a}$ & $4.21 \pm 0.39^{a}$ & $3.27 \pm 1.00^{a}$ \\
\hline
\end{tabular}

The number followed by the same letter in the same column shows no significant difference $(p>0.05)$. $\left({ }^{*}\right)$ : Score $1=$ very much better than $\mathrm{R}, 3=$ better than $\mathrm{R}, 5=$ equal to $\mathrm{R}, 7=$ worse than $\mathrm{R}, 9=$ very much worse than $\mathrm{R}$. $\mathrm{R}$ : salted egg with salt paste control $(\mathrm{NaCl}+$ brick-ash mixture).

eggs. The use of $\mathrm{KCl}$ significantly increased the free radical scavenging activity of salted eggs. The higher $\mathrm{KCl}$ substitution, the higher the radical scavenging activity. Al-Dabbas et al. (23), reported that the presence of inorganic salts has an effect on the DPPH radical scavenging activity. Potassium salt $(K)$ increases the DPPH radical scavenging activity of BHT.

Teak leave extracts added to the salt paste at the concentration of $100 \%$ significantly increased the total phenolic content as well as the antioxidant activity of salted egg produced. This was because teak leave extract contains phenolic compounds that are known to play the role of antioxidant by the mechanism of donating hydrogen atoms to radical compounds.

The addition of teak leave extract at the concentration of $75 \%$ significantly increased the free radical scavenging activity of the salted eggs although it did not significantly affect the total phenolic content. This indicated that although the contribution of teak leave extract on the phenolic content was relatively small, so it was not significantly different from salted eggs without the addition of teak leave extract (P2), but the phenolic compound had high free radical scavenging capability thus significantly increase free radical scavenging activity of salted eggs prepared by the addition of teak leave extract (P2, E2).

\section{Nutritional quality of salted eggs prepared with selected salt paste formula}

Eggs contribute significantly to a healthy diet. Each $100 \mathrm{~g}$ of eggs provides $151 \mathrm{kcal}$ of energy, $12.5 \mathrm{~g}$ of protein, $11.2 \mathrm{~g}$ of fat, some vitamins such as vitamin $\mathrm{D}$, riboflavin and vitamin B12, folate, choline, biotin, phosphorus, selenium, and zinc (1). Based on nutritional composition, eggs are nutrientdense foods and can be consumed by children during growth, pregnant women, nursing mothers, and those who are in the process of healing after illness (2). According to Nio (24), the egg white nutritional composition consisted of $87.8 \%$ water, $10 \%$ protein (albumin, ovalbumin, mucin), $0.05 \%$ fat. The egg yolks composed of $49.05 \%$ water, $16.7 \%$ protein, and $31.6 \%$ fat. The nutritional composition of a whole egg was $73.7 \%$ water, $13.4 \%$ protein and $10 \%$ fat.

Egg consumption is generally intended to get a nutritional component. Therefore, this study also examined the nutritional quality of salted eggs prepared with selected salt paste formulas through measurement of moisture, protein, fat, total minerals, and carbohydrate levels. Table 3 showed that salted eggs produced using selected salt paste formulas have nutritional quality (moisture, protein, total minerals, and carbohydrate contents) that were comparable to the salted egg prepared with control formula. This result suggested that the 


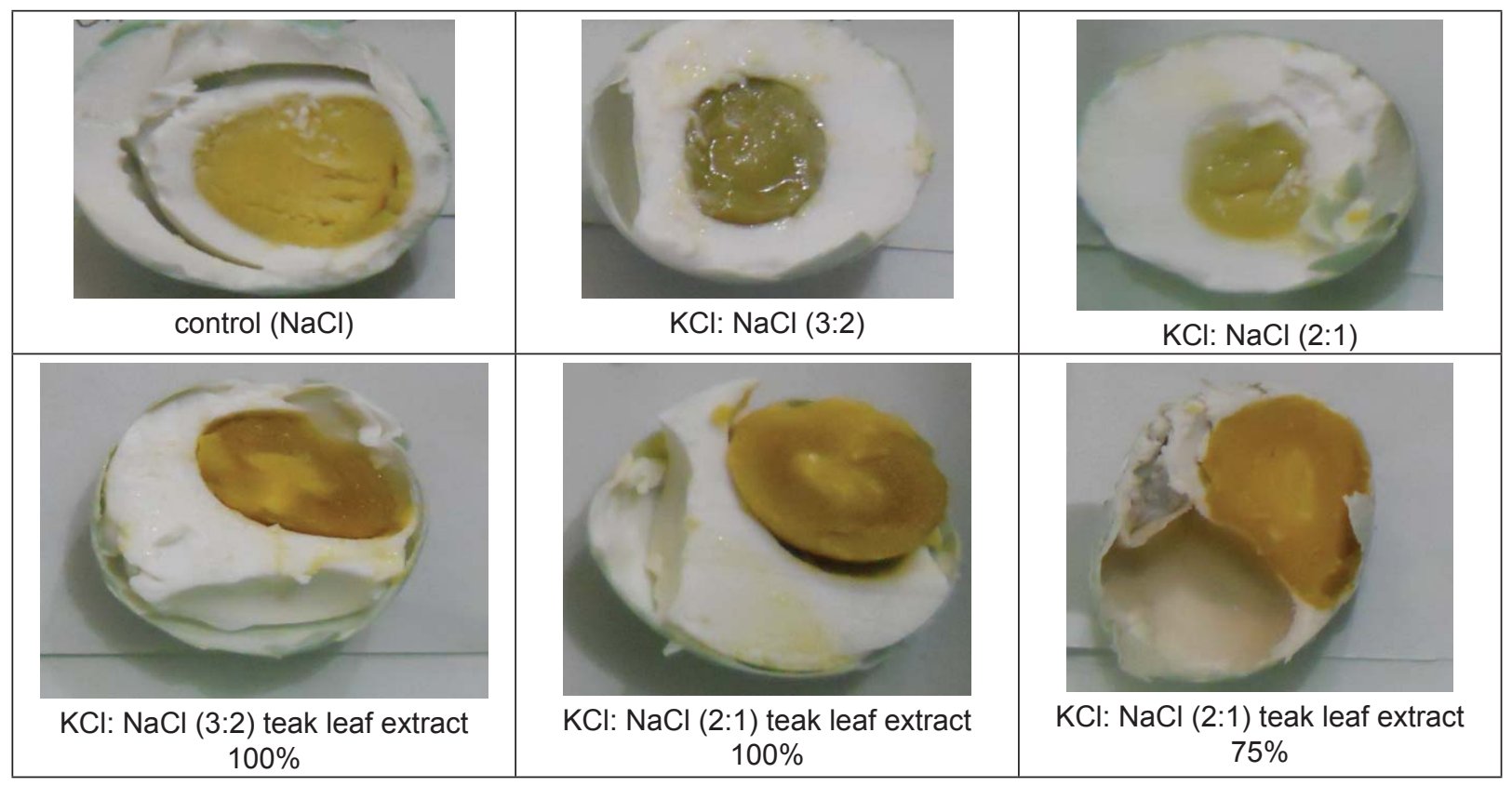

Figure 1. Appearance of salted eggs produced with various salt paste formulas

development of low-sodium salted eggs having antioxidant potency through $\mathrm{KCl}$ substitution and the addition of teak leave extract to the salt paste is very likely to be done.

\section{The sensory quality of the salted egg prepared with selected salt paste formula}

The addition of teak leave extract at the concentration of $75 \%$ and $100 \%$ could improve the egg yolk color quality of the salted egg. This was possible because the absorption of teak leave extracts that having dark red color into the yolk, thus give the higher red yellow color intensity. The color of egg yolks and egg whites made with various salt paste formulas are presented in Figure 1.

The taste and flavor quality improvement of salted eggs with selected salt paste formulas indicated that the astringent taste of the tannin compound present in the teak leave extract covers up the bitter taste of $\mathrm{KCl}$. The savory flavor which typical of teak leaves covers the drug flavor from $\mathrm{KCl}$, so the addition of teak leave extract improved the flavor quality of salted egg prepared with $\mathrm{KCl}$ substitution. Teak leaf buds water extract have red dark color, typical flavor, and astringent taste (25). It could be concluded that the production of salted eggs with the $\mathrm{KCl}$ substitution and the addition of teak leave extract using selected salt paste formulas provided better sensory quality than that of control formula. These results proved that it was possible to develop low-sodium salted egg having potentially antioxidant by the innovation of salting process using selected salt paste formulas

\section{CONCLUSIONS AND RECOMMENDATIONS}

Salted eggs produced using salt paste with $\mathrm{KCl}$ salt substitution that was intended to reduce sodium level of the salted eggs have a comparable antioxidant potency to the salted eggs that prepared without $\mathrm{KCl}$ substitution, unfortunately exhibits inferior sensory qualities. The addition of teak leave extract increased the antioxidant potential and improve the sensory quality of salted egg prepared using $\mathrm{KCl}$ substitution. The low-sodium salted eggs having antioxidant potency made using selected salt formulas showed the nutritional quality that comparable with the salted egg prepared using control formula, even providing better sensory quality.

Research on the effect of low-sodium salted eggs diets on both normal and hypertensive 
blood pressure, and research on potassium (K) bioavailability was needed to be done to provide more comprehensive information about the health benefits of the low-sodium salted eggs. The information is very useful for the development of low sodium salted eggs that can be consumed for hypertension patient and also as an alternative source of potassium intake (K).

\section{REFERENCES}

1. Ruxton CHS, Derbyshire E, Gibson S.The nutritional properties and health benefit of eggs. Nutrition and Food Science 2010;40(3): 263279. doi: $10.1108 / 00346651011043961$

2. Miranda JM, Anton X, Redodo-Valbuena C, Roca-Saavedra P, Rodriguez J, Lamas A, et al. Egg and egg-derived foods: Effects on human health and use as functional foods. Nutrients 2015;7: 706-729.doi:10.3390/nu7010706

3. Matsuoka R, Takahashi Y, Masuda Y, and Kunou M. Heating has no effect on the net protein utilisation from egg whites in rats. The Scientific World Journal 2017;2017: 1-5. doi:10.1155/2017/6817196

4. Suprapti, ML. Pengawetan Telur. Yogyakarta: Kanisius; 2002.

5. Rukmiasih, Ulupi N, Indriani W. Sifat fisik, kimia dan organoleptik telur asin melalui penggaraman dengan tekanan dan konsentrasi garam yang berbeda. Jurnal IImu Produksi dan Teknologi Hasil Peternakan 2015:3(3):142-145

6. Kaewmanee T, Benjakul S, and Visessan W. Effect of salting processes on chemical composition, textural properties and microstructure of duck egg. Journal of the Science of Food and Agriculture 2009; 89(4):625-633.

7. Adrogué HJ, and Madias N E. Sodium and Potassium in the Pathogenesis of Hypertension. The New England Journal of Medicine 2007;356:1966-1978

8. Anggara FHD dan Prayitno N. Faktor-faktor yang berhubungan dengan tekanan darah di puskesmas Telaga murni, Cikarang barat tahun 2012. Jurnal IImiah Kesehatan 2013;5(1): 20 25
9. Perez $V$ and Chang ET. Sodium-to-potassium ratio and blood pressure, hypertension, and related factors. Advances in Nutrition 2014;5:712-741

10. McDonough AA, and Nguyen MTX. How does potassium supplementation lower blood pressure? American Journal of Physiology Renal Physiology 2012;302: F1224-F1225. doi:10.1152/ajprenal.00429.2011

11. Rodrigues SL, Baldo MP, Machado RC , Forechi L, Molina, MCB, and Mill JG. High potassium intake blunts the effect of elevated sodium intake on blood pressure levels. Journal of the American Society of Hypertension 2014;8(4):232-238.

12. Hartati R, Gana SA and Ruslan K. Telaah Flavonoid dan Asam Fenolat Daun Jati. Bandung: Institut Teknologi Bandung; 2007.

13. Ferreira RQ, Greco SJ, Delarmelina $M$, and Weber KC. Electrochemical quantification of the structure/antioxidant activity relationship of flavonoids. Electrochimica Acta 2015;163:161166

14. Kirschweng B,Tatraaljai D, Foldes E, and Pukanszky B. Natural antioxidants as stabilizers for polymers. Polymer Degradation and Stability 2017; 145:25-40

15. Meilgaard M, Civille GV, and Carr BT. Sensory Evaluation Techniques. Third edition., Boca Raton: CRC Press; 1999.

16. Singleton VL. and Rossi JA. Colorimetry of total phenolics with phosphomolybdic phosphotungstic acid reagents. 1965. In Yan LY, Teng LT dan Jhi TJ. Antioxidant properties of guava fruit: comparison with some local fruits. Sunway Academic Journal 2006;3: 9-20

17. Sharma OP and Bhat TK. DPPH antioxidant assay revisited. Food Chemistry 2009;113:12021205

18. AOAC. Official method of analysis of the association of official analytical chemist15th Edition. Washington, DC: Association Official Analytical Chemists; 1990.

19. Pereira DM, Valentão P, Pereira JA, and Andrade PB. Phenolics: From chemistry to biology. Molecules 2009;14:2202-2211.doi:10.3390/ molecules 14062202 
20. Sujana E, Wahyuni S dan Burhanudin H. Efek pemberian ransum yang mengandung tepung daun singkong, daun ubi jalar, dan eceng gondok sebagai sumber pigmen karotenoid terhadap kualitas kuning telur itik tegal. Jurnal IImu Ternak 2006;6(1): 53 - 56.

21. Saty L, Praseno K dan Kasiyati. Kadar kolesterol dan $\beta$-karoten telur itik dari beberapa lokasi budidaya itik di Jawa. Buletin Anatomi dan Fisiologi 2014;XXII(2): 56 - 63

22. Nderitu AM, Dykes L, Awika JM, Minnaar A and Duodu KG. Phenolic composition and inhibitory effect against oxidative DNA damage of cooked cowpeas as affected by simulated in vitro gastrointestinal digestion. Food Chemistry 2013;141(3): 1763-1771

23. Al-Dabbas MM, Al-Ismail K, Kitahara K, Chishaki $\mathrm{N}$, Hashinaga $\mathrm{F}$, Suganuma $\mathrm{T}$ and Tadera $\mathrm{K}$. The effects of different inorganic salts, buffer systems, and desalting of Varthemia crude water extract on DPPH radical scavenging activity. Food Chemistry 2007 104: 734-739

24. Nio OK. Daftar Analisis Bahan Makanan. Jakarta: Universitas Indonesia press; 1992.

25. Setijo P dan Zumiati. 2009. Pewarna Nabatai Makanan. Yogyakarta: Kanisius; 2009 